\title{
KOMPARASI KINERJA ALGORITMA FUZZY C-MEANS DAN K-MEANS DALAM PENGELOMPOKAN DATA SISWA BERDASARKAN PRESTASI NILAIAKADEMIK SISWA
}

( Studi Kasus : SMP Negeri 2 Pematangsiantar )

\author{
Nelson Butarbutar ${ }^{1}$, Agus Perdana Windarto ${ }^{2}$, Dedi Hartama ${ }^{3}$, Solikhun $^{4}$ \\ Mahasiswa STIKOM Tunas Bangsa Pematangsiantar ${ }^{1}$ \\ Dosen STIKOM Tunas Bangsa Pematangsiantar ${ }^{2,3,4}$ \\ E-mail : nbutarbutar@gmail.com ${ }^{1}$, zhantura.gusti@gmail.com², \\ solikhun@amiktunasbangsa.ac.id ${ }^{3}$, dedyhartama@amiktunasbangsa.ac.id ${ }^{4}$
}

\begin{abstract}
Abstrak
Berbagai upaya telah dilakukan oleh pihak sekolah untuk meningkatkan prestasi akademik siswa sebagai upaya untuk mencapai standar pendidikan nasional. Salah satunya adalah dengan melakukan bimbingan belajar pada masing-masing siswa, namun hasilnya belum begitu memuaskan. Hal ini disebabkan karena pihak sekolah khususnya bagian pendidikan tidak memahami sepenuhnya kemampuan masing-masing siswa dalam menguasai suatu mata pelajaran khususnya mata pelajaran inti UN. Untuk mengatasi hal ini dengan memanfaatkan teknik clustering akan dilakukan pengelompokan data siswa berdasarkan prestasi nilai akademik yang sumber datanya diperoleh langsung dari bagian pendidikan. Dengan menggunakan teknik clustering, bagian pendidikan akan lebih mudah mendata siswanya berdasarkan kemampuannya masing-masing sesuai dengan prestasi nilai akademiknya. Teknik clustering yang digunakan dalam penelitian ini adalah algoritma Fuzzy C-Means dan K-Means. Berdasarkan hasil penelitian yang dilakukan dapat disimpulkan bahwa teknik clustering yang paling tepat digunakan dalam melakukan pengelompokan data siswa adalah algoritma K-Means dengan jumlah interasi sebanyak 11 untuk mendapatkan cluster data siswa sedangkan algoritma Fuzzy C-Means membutuhkan proses interasi yang panjang sebanyak 35 interasi dan proses perhitungan yang rumit serta hasil cluster data siswa kurang akurat dibandingkan menggunakan algoritma K-Means.
\end{abstract}

Kata kunci : Standar pendidikan nasional; UN, clustering; fuzzy C-Means; K-Means

\section{Pendahuluan}

Kurikulum adalah seperangkat rencana dan pengaturan mengenai tujuan, isi dan bahan pelajaran serta cara yang digunakan sebagai pedoman penyelenggaraan kegiatan pembelajaran untuk mencapai tujuan pendidikan tertentu. Tujuan pendidikan itu adalah mencapai standar pendidikan nasional yang meliputi standar isi, proses, kompetensi lulusan, tenaga kependidikan, sarana dan prasarana, pengelolaan, pembiayaan dan penilaian pendidikan. Dalam proses pendidikan di sekolah pihak akademik harus memahami kemampuan masing-masing siswa dalam menguasai suatu ilmu yang diajarkan disekolah karena hal ini sangat menentukan prestasi masing-masing siswa. Dalam sebuah institusi pendidikan kwalitas akademik masing-masing sekolah diukur berdasarkan prestasi nilai akademik masing-masing siswa baik itu nilai akademik setiap semester maupun nilai Ujian Nasional.

Berbagai penelitian telah dilakukan dengan menggunakan teknik clustering dalam mengelompokkan data siswa berdasarkan data nilai.Miftahus S., at al,.(2012) menggunakan teknik klasifikasi dalam mengelompokkan data nilai siswa untuk memprediksi tingkat kelulusan siswa dalam menghadapi UN.Suprihatin, (2011) 
menggunakan teknik clustering algoritma $K$-Means dalam menentukan nilai ujian.Anita B. H., at al., (2013) dalam penelitiannya menggunakan algoritma Fuzzy C-Means dan TOPSIS dalam mengelompokkan data siswa berdasarkan nilai prestasi akademik mata pelajaran peminatan, minat terhadap jurusan, nilai IQ serta kuota kelas yang tersedia.

Pada saat ini masing-masing sekolah khususnya pada tingkat Sekolah Menengah Pertama berusaha mempersiapkan masingmasing siswanya dalam menghadapi Ujian Nasional yang akan dilaksankan pada saat akhir studi. Berbagai upaya telah dilakukan seperti mengadakan bimbingan belajar, namun hasil yang diharapkan belum begitu memuaskan.Hal ini tentu disebabkan karena pihak sekolah khususnya bagian pendidikan tidak memahami kemampuan masingmasing siswa dalam menguasai suatu mata pelajaran khususnya mata pelajaran inti UN.Untuk itu melalui penelitian ini diusulkan sebuah teknik clustering untuk mengelompokkan data siswa berdasarkan kemampuannya dalam menguasai materi mata pelajaran berdasarkan nilai akademiknya.Dengan menggunakan teknik clustering bagian pendidikan akan lebih mudah mendata siswanya sesuai dengan kemampuannya masing-masing, sehingga pada saat kenaikan kelas bagian pendidikan dapat menempatkan siswa dalam satu kelas sesuai dengan kemampuan masing-masing siswa agar pihak guru ataupun wali kelas dapat menerapkan metode pengajaran yang tepat sehingga setiap siswa dapat meningkatkan prestasi akademiknya. Dalam penelitian ini teknik clustering yang digunakan adalah algoritma Fuzzy C-Means dan algoritma $K$-Means. Setelah dilakukan pengelompokan menggunakan kedua algoritma tersebut, selanjutnya akan dilakukan analisis komparasi kinerja kedua algoritma tersebut dalam melakukan pengelompokan data siswa.

Penelitian ini dilakukan untuk memudahkan pihak sekolah khususnya bagian pendidikan dalam mendata siswa sesuai dengan kemampuannya masingmasing melalui prestasi nilai akademik siswa dengan mengusulkan sebuah teknik clustering dalam mengelompokkan data siswa.

1. Mengimplementasikan teknik clustering metode Fuzzy C-Means dan K-Means dalam melakukan clustering data siswa.

\section{Kajian Teori}

\section{Data Mining}

Manusia dalam suatu organisasi, sadar atau tidak sadar telah memproduksi berbagai data yang jumlahnya sangat besar.Pada dasarnya data adalah entitas yang tidak memiliki arti, meskipun kemungkinan memiliki nilai di dalamnya. Data mining merupakan disiplin ilmu yang mempelajari metode untuk mengestrak pengetahuan atau menemukan pola dari suatu data, sehingga data mining sering juga disebut Knowledge Discovery in Database (KDD).

Konsep utama dari sebuah transformasi dalam data mining adalah suatu kumpulan data yang bersumber dari database yang berukuran besar yang diekstrak dan dirangkum untuk menemukan suatu pola berupa informasi yang bermanfaat dan mengandung sebuah pengetahuan yang dapat digunakan untuk membantu pengambil keputusan dalam mengambil kebijakan yang tepat untuk kepentingan sebuah organisasi.

Data mining dapat juga didefenisikan sebagai gabungan dari suatu pengalaman, nilai, informasi kontekstual dan juga pandangan pakar yang memberikan suatu framework untuk mengevaluasi dan menciptakan pengalaman baru dan informasi ( Thomas H. Davenport, Laurence Prusak ).

\section{Clustering}

Clustering adalah pengelompokan data, hasil observasi dan kasus ke dalam class yang mirip. Suatu cluster adalah koleksi data yang mirip antara satu dengan yang lain, dan memiliki perbedaan bila 
dibandingkan dengan data dari cluster lain. Perbedaan utama algoritma clustering dengan klasifikasi adalah clustering tidak memiliki target/class/label, jadi unsupervised learning. Clustering sering digunakan sebagai tahap awal dalam proses data mining, dengan hasil cluster yang terbentuk akan menjadi input dari algoritma berikutnya yang digunakan. Ada beberapa pendekatan yang digunakan dalam mengembangkan metode clustering.Dua pendekatan utama tersebut adalah clustering dengan pendekatan partisi dan clustering dengan pendekatan hirarki.Disamping kedua pendekatan tersebut, ada juga clustering dengan pendekatan automatic mapping (SelfOrganising Map/SOM).

\section{Algoritma K-Means}

Algoritma K-Means merupakan salah satu algoritma clustering yang digunakan untuk mempartisi data kedalam beberapa cluster, dimana data yang memiliki tingkat kemiripan yang tinggi dikelompokkan dalam satu cluster sedangkan data yang memiliki karakteristik yang berbeda dikelompokkan ke dalam cluster yang berbeda.

\section{Metode Penelitian}

Dalam metode clustering konsep utama yang ditekankan adalah pencarian pusat cluster secara iteratif, dimana pusat cluster ditentukan berdasarkan jarak minimum setiap data pada pusat cluster.

Langkah- langkah penyelesaian algoritma $K$-Means dapat diuraikan sebagai berikut :

1. Identifikasi data yang akan dicluster dan juga tentukan jumlah cluster data, $\mathrm{X}_{\mathrm{ij}}(\mathrm{i}=1,2, \ldots . \mathrm{n} ; \mathrm{j}=1,2, \ldots . \mathrm{m})$ dimana $\mathrm{n}$ adalah jumlah data yang akan di cluster dan $m$ adalah jumlah variabel data.

2. Pada awal interasi pusat setiap cluster ditentukan secara acak (sembarang), $\mathrm{C}_{\mathrm{kj}}(\mathrm{k}=1, \ldots . . \mathrm{k} ; \mathrm{j}=1, \ldots . . \mathrm{m})$.

3. Tentukan jarak setiap data terhadap pusat cluster dengan menggunakan formula Euclidean berikut :

$$
d_{i k}=\sqrt{\sum_{j=1}^{m}\left(X_{i j}-C_{k j}\right)^{2}}
$$

4. Kelompokkan data berdasarkan jarak minimum data terhadap pusat cluster.

5. Cek kondisi apakah ada data yang masih pindah pada kelompok lain, jika ia lakukan interasi berikutnya dengan menghitung pusat cluster berdasarkan nilai rata-rata dari data yang menjadi anggota pada cluster yang terbentuk hasil interasi sebelumnya dengan menggunakan rumus :

$$
C_{k j}=\frac{\sum_{i=1}^{p} X_{i j}}{p} ;
$$

Dimana $X_{\mathrm{ij}} \in$ cluster ke-k dan adalah jumlah anggota cluster

6. Jika tidak ada lagi data yang pindah pada cluster lain, maka proses interasi berhenti.

Dalam algoritma K-Means suatu data di kelompokkan pada suatu cluster jika data tersebut memiliki jarak minimum terhadap pusat cluster yang dapat dihitung dengan menggunakan rumus (2.1). Untuk memudahkan pemahaman kita tentang impelementasi penggunaan algoritma $K$ Means, contoh hasil perhitungan algoritma $K$-Means dapat kita lihat pada tabel 1 berikut :

Tabel 1. Contoh Hasil Perhitungan Menggunakan Algoritma $K$ -

\begin{tabular}{|c|c|c|c|c|c|c|}
\hline \multicolumn{3}{|c|}{ Derajat Keanggotaan ${ }^{3}$} & Jarak & \multicolumn{3}{|c|}{ Cluster } \\
\hline $\mathrm{di}_{\mathrm{i}}$ & $\mathrm{d}_{\mathrm{i}}$ & $\mathrm{di}_{\mathrm{i}}$ & Minimum & $\mathrm{C}$ & C & $\mathrm{C}$ \\
\hline 2.3764 & 3.6245 & 1.2547 & 1.2547 & 0 & 0 & 1 \\
\hline 5.2635 & 1.2356 & 2.3746 & 1.2356 & 0 & 1 & 0 \\
\hline 3.5476 & 2.3669 & 3.4648 & 2.3669 & 0 & 1 & 0 \\
\hline 4.0887 & 2.0187 & 3.2863 & 2.0187 & 0 & 1 & 0 \\
\hline 1.2384 & 3.4658 & 4.2974 & 1.2384 & 1 & 0 & 0 \\
\hline 4.2929 & 2.3648 & 1.2394 & 1.2394 & 0 & 0 & 1 \\
\hline 2.9383 & 4.2722 & 3.0883 & 2.9383 & 1 & 0 & 0 \\
\hline 1.0927 & 2.3937 & 1.2533 & 1.0927 & 1 & 0 & 0 \\
\hline
\end{tabular}
Means

Algoritma Fuzzy C-Means (FCM) 
Fuzzy C-Means adalah salah satu metode fuzzy clustering yang pertama sekali dikembangkan oleh Dunn (1973) dan kemudian diperbaiki oleh Bezdek (1981) sebagai metode yang sering digunakan dalam pengenalan pola (pattern recognition).Dalam FCM pengelompokan data dilakukan berdasarkan derajat keanggotaan yang bernilai antara 0 dan 1 . Dalam algoritma FCM langkah pertama yang dilakukan adalah menentukan pusat cluster yang akan menandai lokasi rata-rata untuk tiap cluster. Pada kondisi awal, pusat cluster ini masih belum akurat.Tiap tiap data memiliki derajat keanggotaan untuk tiap-tiap cluster. Dengan cara memperbaiki pusat cluster dan nilai keanggotaan tiap-tiap data secara berulang, maka dapat dilihat bahwa pusat cluster akan menuju lokasi yang tepat. Perulangan ini didasarkan pada minimasi fungsi objektif yang menggambarkan jarak dari titik data yang diberikan ke pusat cluster yang terbobot oleh derajat keanggotaan titik data tersebut. Output dari FCM bukan merupakan fuzzy inference system, namun merupakan deretan pusat cluster dan beberapa derajat keanggotaan untuk tiap-tiap titik data.

Langkah-langkah penyelesaian algoritma Fuzzy C-Means dapat diuraikan sebagai berikut :

1. Identifikasi data yang akan di cluster berupa matriks berukuran $\mathrm{n} \times \mathrm{m}\left(\mathrm{X}_{\mathrm{ij}}=\right.$ data sampel ke-i $(\mathrm{i}=1,2, \ldots \mathrm{n})$ dan atribut ke-j $(j=1,2, \ldots m)$.

2. Menentukan jumlah cluster (c), pangkat (w), maksimum interasi (maxiter), error terkecil yang diharapkan $(\mathcal{E})$, fungsi objektif awal $\left(\mathrm{P}_{0}=0\right)$ dan interasi awal $(\mathrm{t}=1)$.

3. Membangkitkan bilangan random $\mu_{\mathrm{ik}}$ (i $=1,2, . ., \mathrm{n} ; \mathrm{k}=1,2, . ., \mathrm{c})$ sebagai elemenelemen matriks partisi awal U.

Menghitung jumlah setiap kolom dengan rumus :

$$
\mathrm{Q}_{\mathrm{j}}=\sum_{k=1}^{c} ?_{i k}
$$

Mengitung nilai elemen matriks partisi anggota himpunan $\mathrm{U}$ dengan rumus :

$$
\mu_{\mathrm{ik}}=\frac{\operatorname{Q⿱一}_{i k}}{Q_{i}}
$$

4. Menghitung nilai pusat cluster $\mathrm{ke}-\mathrm{k}\left(\mathrm{V}_{\mathrm{kj}}\right.$ dengan $\mathrm{k}=1,2, . ., \mathrm{c} ; \mathrm{j}=1,2, \ldots, \mathrm{m})$

5. Men

teta-inter(asi)

ke-t (....

$$
\begin{gathered}
P_{t}=\sum_{i=1}^{n} \sum_{k=1}^{c}\left(\left[\sum _ { j = 1 } ^ { m } \left(X_{i j}^{-(2.6)}\right.\right.\right. \\
\left.\left.\left.-V_{k j}\right)^{2}\right]\left(\mu_{i k}\right)^{w}\right)
\end{gathered}
$$

6. Menghitung perubahan matriks partisi $\mathrm{U}$ :

$$
\mu_{\mathrm{ik}}=\frac{\left[\sum_{j=1}^{m}\left(X_{i j}-V_{k j}\right)^{2}\right]^{\frac{-1}{w-1}}}{\sum_{k=1}^{c}\left[\sum_{j=1}^{m}\left(X_{i j}-V_{k j}\right)^{2}\right]^{\frac{-1}{w-1}}}
$$

7. Cek kondisi berhenti:

a. Jika $\left(\mathrm{P}_{\mathrm{t}}-\mathrm{P}_{\mathrm{t}-1}\right)<\mathcal{E}$ atau $(\mathrm{t}<$ MaxIter $)$ maka interasi berhenti.

b. Jika tidak : $\mathrm{t}=\mathrm{t}+1$, ulangi langkah 4 sampai 7.

Dalam algoritma Fuzzy C-Means suatu data dikelompokkan dalam suatu cluster, jika data memiliki nilai jarak maksimum partisi matriks $U\left(\mu_{\mathrm{ik}}\right)$ terhadap pusat cluster. Untuk memudahkan pemahaman implementasi algoritma Fuzzy C-Means, berikut contoh tabel 2 hasil

\begin{tabular}{|c|c|c|c|c|c|c|}
\hline \multicolumn{3}{|c|}{ Derajat Keangogtaan } & \multirow{2}{*}{$\begin{array}{c}\text { Jarak } \\
\text { Maksimum }\end{array}$} & \multicolumn{3}{|c|}{ Klaster } \\
\hline$\mu_{\mathrm{i}}$ & $\mu_{\mathrm{i}}$ & $\mu_{\mathrm{i}}$ & & C & $\bar{C}$ & $\bar{C}$ \\
\hline 0.456 & 0.284 & 0.260 & 0.456 & 1 & 0 & 0 \\
\hline 0.282 & 0.123 & 0.595 & 0.595 & 0 & 0 & 1 \\
\hline 0.564 & 0.234 & 0.202 & 0.564 & 1 & 0 & 0 \\
\hline 0.234 & 0.554 & 0.212 & 0.554 & 0 & 1 & 0 \\
\hline 0.345 & 0.432 & 0.223 & 0.432 & 0 & 1 & 0 \\
\hline 0.371 & 0.123 & 0.506 & 0.506 & 0 & 0 & 1 \\
\hline 0.653 & 0.231 & 0.116 & 0.653 & 1 & 0 & 0 \\
\hline 0.354 & 0.213 & 0.433 & 0.433 & 0 & 0 & 1 \\
\hline
\end{tabular}
perhitungan algoritma Fuzzy C-Means :

Tabel 2. Contoh hasil perhitungan menggunakan algoritma Fuzzy C-Means

Standar Penilaian Pendidikan 
Undang-Undang Nomor 20 Tahun 2003 tentang Sistem Pendidikan Nasional. Pasal 1 angka 1 menyatakan bahwa "pendidikan adalah usaha sadar dan terencana untuk mewujudkan suasana belajar dan proses pembelajaran agar peserta didik secara aktif mengembangkan potensi dirinya untuk memiliki kekuatan spiritual keagamaan, pengendalian diri, kepribadian, kecerdasan, akhlak mulia, serta keterampilan yang diperlukan dirinya, masyarakat, bangsa dan negara". Standar Nasional Pendidikan berfungsi sebagai dasar perencanaan, pelaksanaan, dan pengawasan pendidikan dalam rangka mewujudkan pendidikan nasional yang bermutu. Salah satu bagian dari Standar Pendidikan Nasional adalah Standar Penilaian yang bertujuan untuk menjamin :

1. Perencanaan penilaian peserta didik sesuai dengan kompetensi yang akan dicapai dan berdasarkan prinsip-prinsip penilaian.

2. Pelaksanaan penilaian peserta didik secara profesional, terbuka, edukatif, efektif, efisien dan sesuai dengan konteks sosial budaya.

3. Pelaporan hasil penilaian peserta didik secara objektif, akuntabel dan informatif.

Standar Penilaian Pendidikan adalah kriteria mengenai mekanisme, prosedur, dan instrumen penilaian hasil belajar peserta didik.

\section{Hasil dan Pembahasan}

Penelitian ini dilakukan untuk mengetahui tingkat kemampuan masingmasing siswa dalam memahami dan menguasai ilmu yang di pelajari, dengan melakukan clustering terhadap data siswa yang sudah mengikuti ujian akhir semester genap berdasarkan nilai mata pelajaran inti UN ( Bahasa Inggris, Bahasa Indonesia, Matematika, dan IPA) dan nilai rata-rata rapor. Hasil clustering data siswa nantinya akan dijadikan sebagai dasar untuk pembagian kelas oleh bagian pendidikan pada saat kenaikan kelas. Melalui hasil penelitian ini, diharapkan pihak pendidikan dapat menentukan kebijakan yang tepat dalam menerapkan metode pengajaran yang akan dilakukan oleh masing-masing guru sesuai dengan kemampuan masing-masing siswa. Selain itu juga, melalui hasil penelitian ini bagian pendidikan dapat memantau perkembangan kemampuan masing-masing siswa dalam menguasai mata pelajaran khususnya mata pelajaran inti UN. Sehingga nantinya setiap siswa lebih siap dalam menghadapi Ujian Nasional, yang akan diadakan pada akhir masa studi serta tingkat kelulusan siswa dapat lebih di maksimalkan. Dalam penelitin ini clustering data siswa dilakukan dengan menggunakan algoritma Fuzzy $C$ Means dan algoritma $K$-Means.Selain untuk menentukan clustering data siswa, penelitian ini juga dilakukan untuk melakukan analisis komparasi kinerja metode Fuzzy $C$-Means dan metode $K$ Means dalam melakukan pengelompokan data siswa.

Data penelitian diperoleh langsung dari bagian pendidikan dengan jumlah data sebanyak 150 record data siswa. Data yang diperoleh, disimpan pada database Mysql agar dapat diproses menggunakan aplikasi prototypeclustering. Berikut adalah data nilai siswa yang berhasil diperoleh :

Tabel 3. Data nilai siswa 
JURASIK (Jurnal Riset Sistem Informasi \& Teknik Informatika)

Volume 1, Nomor 1, Juli 2016

\begin{tabular}{|c|c|c|c|c|c|c|}
\hline \multirow{2}{*}{ Nomor } & \multirow{2}{*}{ Nama Sivina } & \multicolumn{5}{|c|}{ 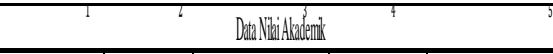 } \\
\hline & & Baldarag havis $\left(X_{i}\right)$ & Naternitia $X_{i}$ & Bdansalmonasia $\left(X_{i}\right)$ & $\mathbb{P A}\left(X_{i}\right)$ & 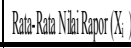 \\
\hline 1 & Dede Surahman & 8.5 & 7.50 & 7.10 & 6.75 & 7.10 \\
\hline 2 & Irinilnarawail & 5.50 & 5.65 & 6.50 & 4.50 & 3.50 \\
\hline 3 & Sineraithri & 4.00 & 5.50 & 7.5 & 5.00 & 6.00 \\
\hline 4 & Amingyititi & 7.25 & 7.10 & 9.00 & 8.50 & 8.20 \\
\hline$j$ & Bonosuratman & 8.10 & 7.10 & 8.50 & 7.50 & 7.80 \\
\hline 6 & Parlindungan Sidowutar & 4.25 & 4,10 & 7.10 & 6.10 & 6.20 \\
\hline 1 & Prmans ninage & 6.50 & 6.00 & 7,10 & 6.21 & 6.30 \\
\hline 8 & Ahmad Dari & 7.10 & 6.50 & 8.10 & 6.00 & 6.50 \\
\hline 9 & TotóRhamarar & 4.20 & 5.10 & .3 .00 & 5.00 & 5.10 \\
\hline 10 & Adelina Feronikastituons & 7.00 & 6.50 & 6.50 & 450 & 3.50 \\
\hline 11 & Pituluorang & 4.50 & 5.20 & 6.00 & 5.00 & 5.50 \\
\hline 12 & Alisyeltarana & 9.00 & 8.10 & 8.00 & 7.50 & 7.80 \\
\hline 13 & Romiliana & 8.20 & 7,50 & 7.80 & $6+1)$ & 7.00 \\
\hline 14 & Sulisitionaldil & 4,00 & 5.30 & 6.00 & 650 & 6.30 \\
\hline 15 & Bditetlanurung & 6.20 & 5.10 & 7,30 & 630 & 6.50 \\
\hline 16 & Ranolanonosingag & 5.50 & 6.20 & 7,30 & 6.00 & 7.00 \\
\hline 17 & Sisilowardono & 7.20 & 6.70 & 7.30 & 6.21 & 6.80 \\
\hline 18 & Roollendit & 4.20 & 5.50 & 7.20 & 6.00 & 7.20 \\
\hline 19 & Endongensuati & 5,30 & 6.0 & 7.60 & 6.90 & 7.00 \\
\hline 20 & homsons Sodoutar & 4.25 & 5.80 & 6.20 & 6.21 & 6.50 \\
\hline 21 & Prolingarturin & 7.80 & 6.40 & 8.30 & 7.50 & 7.70 \\
\hline 2 & Totonondarabaggh & 8.20 & 9.10 & 7.40 & 6.00 & 7.90 \\
\hline 23 & Pregreang hitudarat & 5.01 & 4.60 & 5.20 & 6.30 & 5,30 \\
\hline 24 & Surit larabari & 4.20 & 4.70 & 5.40 & 6.30 & 6.00 \\
\hline 25 & Ontionghadi & 6.30 & 6.30 & 7.30 & 6.210 & 6.60 \\
\hline "."' & $\ldots$ & $\ldots$ & $\ldots$ & $\ldots$ & $\ldots$ & $\ldots$ \\
\hline ..." & $\ldots$ & $\ldots$ & $\ldots$ & $\ldots$ & $\ldots$ & $\ldots$ \\
\hline 149) & Anoi Singage & 6.20 & 7.10 & 6.10 & 6.00 & 6.50 \\
\hline 150 & Pemmensinitit & 7.20 & 6.50 & 7.10 & 6.85 & 6.90 \\
\hline
\end{tabular}

memilih metode yang digunakan untuk melakukan clustering data siswa.

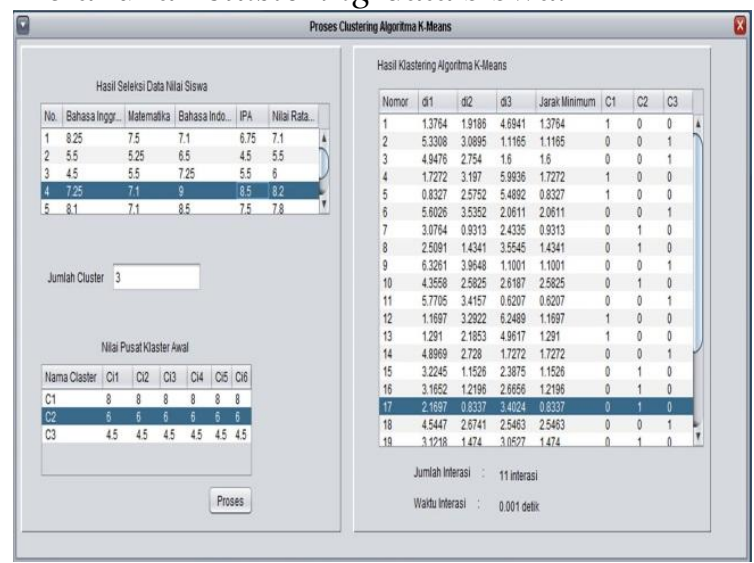

Gambar 2. Halaman proses algoritma $K$ Means

Halaman Proses Algoritma $K$ Means merupakan halaman yang digunakan untuk menampilkan hasil proses perhitungan algoritma $K$-Means. Dari hasil perhitungan dapat kita lihat bahwa proses interasi berhenti pada interasi ke-11 dengan waktu interasi 0.001 detik.

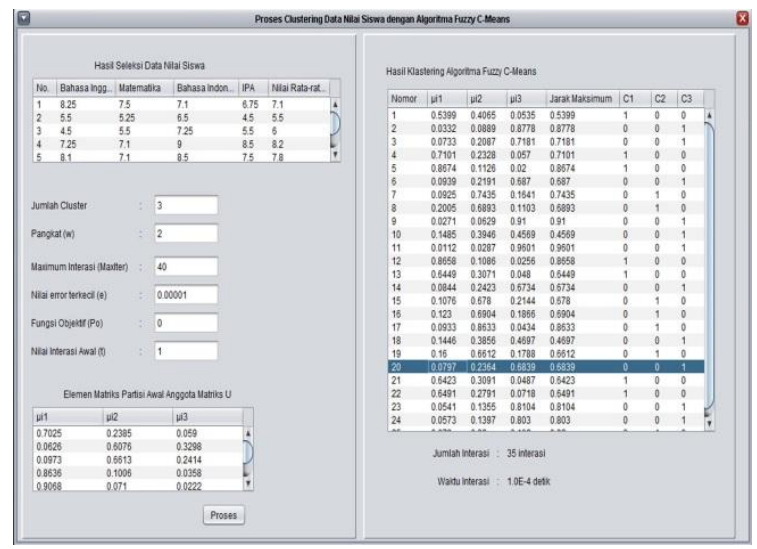

Gambar 3. Halaman proses algoritma Fuzzy C-Means

Halaman Proses Algoritma Fuzzy Cperhitungan clustering digunakan aplikasi prototype clustering yang dibangun dengan menggunakan bahasa pemrograman java. Berikut adalah tampilan aplikasi clustering data siswa :

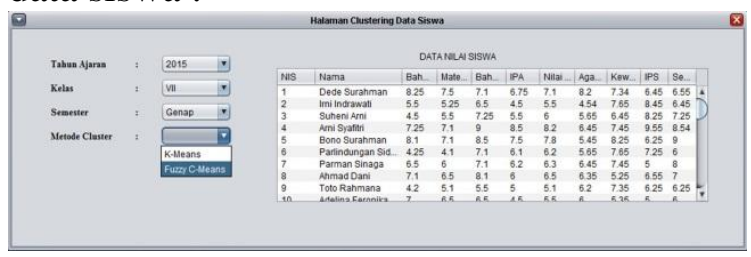

Gambar 1. Halaman cluster data siswa

Halaman Cluster Data Siswa merupakan halaman yang digunakan untuk 
melakukan proses identifikasi terhadap data yang akan dicluster. Dalam hal ini data yang akan dicluster adalah data siswa yang ada pada tabel 3 di atas. Setelah data yang akan dicluster diketahui maka langkah selanjutnya adalah menentukan pusat cluster awal yang ditentukan secara acak. Langkah selanjutnya adalah melakukan perhitungan algoritma K-Means dengan menggunakan aplikasi prototypeclustering. Hasil clustering ditentukan berdasarkan jarak minimum setiap data pada pusat cluster atau proses interasi clustering berhenti jika tidak ada lagi data yang berpindah pada cluster lain. Berdasarkan hasil percobaan yang dilakukan, proses interasi algoritma $K$-Means berhenti pada interasi ke-11. Hasil clustering menggunakan algoritma K-Means dapat kita lihat pada tabel 4 berikut :

Tabel 4. Hasil clustering data siswa menggunakan algoritma $K$ Means

\begin{tabular}{|c|c|c|c|c|c|c|c|}
\hline \multirow{2}{*}{ Nomor } & \multicolumn{3}{|c|}{ Derajat Keanggotaan } & \multirow{2}{*}{$\begin{array}{c}\text { Jarak } \\
\text { Minimum }\end{array}$} & \multicolumn{3}{|c|}{ Cluster } \\
\hline & $d_{i 1}$ & $d_{i 2}$ & $d_{i 3}$ & & $C_{1}$ & $C_{2}$ & $C_{3}$ \\
\hline 1 & 1.3764 & 1.9186 & 4.6941 & 1.3764 & 1 & C & 0 \\
\hline 2 & 5.3308 & 3.0895 & 1.1165 & 1.1165 & & & \\
\hline 3 & 4.9476 & 2.7540 & 1.6000 & 1.6000 & ( & 0 & 1 \\
\hline 4 & 1.7272 & 3.1970 & 5.9936 & 1.7272 & & & U \\
\hline 5 & 0.8327 & 2.5752 & 5.4892 & 0.8327 & & 0 & 0 \\
\hline 6 & 5.6026 & 3.5352 & 2.0611 & 2.0611 & 0 & 0 & 1 \\
\hline 7 & 3.0764 & 0.9313 & 2.4335 & 0.9313 & 0 & 1 & 0 \\
\hline 8 & 2.5091 & 1.4341 & 3.5545 & 1.4341 & 0 & 1 & 0 \\
\hline 9 & 6.3261 & 3.9648 & 1.1001 & 1.1001 & 0 & 0 & 1 \\
\hline 10 & 4.3558 & 2.5825 & 2.6187 & 2.5825 & 0 & 1 & 0 \\
\hline 11 & 5.7705 & 3.4157 & 0.6207 & 0.6207 & 0 & 0 & 1 \\
\hline 12 & 1.1697 & 3.2922 & 6.2489 & 1.1697 & 1 & 0 & 0 \\
\hline 13 & 1.2910 & 2.1853 & 4.9617 & 1.2910 & 1 & 0 & 0 \\
\hline 14 & 4.8969 & 2.7280 & 1.7272 & 1.7272 & 0 & 0 & 1 \\
\hline 15 & 3.2245 & 1.1526 & 2.3875 & 1.1526 & 0 & 1 & 0 \\
\hline 16 & 3.1652 & 1.2196 & 2.6656 & 1.2196 & 0 & 1 & 0 \\
\hline 17 & 2.1697 & 0.8337 & 3.4024 & 0.8337 & 0 & 1 & 0 \\
\hline 18 & 4.5447 & 2.6741 & 2.5463 & 2.5463 & 0 & 0 & 1 \\
\hline 19 & 3.1218 & 1.4740 & 3.0527 & 1.4740 & 0 & 1 & 0 \\
\hline 20 & 4.8443 & 2.6397 & 1.6567 & 1.6567 & 0 & 0 & 1 \\
\hline$\ldots .$. & $\ldots .$. & $\ldots .$. & $\ldots . .$. & $\ldots .$. & $\ldots . .$. & $\ldots . .$. & $\ldots$. \\
\hline$\ldots .$. & $\ldots .$. & ..... & $\ldots . .$. & ...... & $\ldots . .$. & $\ldots .$. & $\cdots$ \\
\hline 149 & 2.7579 & 0.7272 & 2.8906 & 0.7272 & 0 & 1 & 0 \\
\hline 150 & 1.9263 & 0.6998 & 3.5197 & 0.6998 & 0 & 1 & 0 \\
\hline
\end{tabular}

\section{Algoritma Fuzzy C-Means}

Proses pengelompokan data menggunakan algoritma Fuzzy C-Means dilakukan dengan terlebih dahulu melakukan proses identifikasi terhadap data yang akan dicluster. Dalam hal ini data yang akan dicluster adalah data siswa seperti yang terdapat pada tabel 3. Setelah data diidentifikasi, langkah selanjutnya adalah melakukan inisialisasi jumlah cluster, tingkat kekaburan data (W), maximum interasi, akurasi (e), nilai fungsi objektif awal, dan interasi awal.

Dalam proses clustering menggunakan algoritma Fuzzy C-Means langkah pertama yang dilakukan adalah menentukan nilai berikut :

1. Jumlah Cluster (c) $=3$

2. Pangkat $(\mathrm{W}) \quad=2$

3. Maksimum Interasi $=40$

4. Error Terkecil (e) $=10^{-5}$ 
5. Fungsi Objektif Awal $\left(\mathrm{P}_{0}\right)=0$

6. Interas Awal $=1$

Dalam algoritma Fuzzy C-Means proses interasi berhenti jika nilai hasil perhitungan fungsi objektif bernilai positif dan $\left(\left|\mathrm{P}_{\mathrm{t}}-\mathrm{P}_{\mathrm{t}-1}\right|\right)<\mathrm{e}$ (error terkecil). Setelah dilakukan proses interasi menggunakan Fuzzy $C$-Means, proses interasi berhenti pada interasi ke-35 dengan hasil clustering data siswa ditentukan berdasarkan jarak maksimum data pada derajat keanggota cluster data. Hasil clustering data siswa menggunakan Fuzzy C-Means dapat kita lihat pada tabel 5 berikut :

Tabel 5. Hasil clustering data siswa menggunakan algoritma Fuzzy C-Means

\begin{tabular}{|c|c|c|c|c|c|c|c|}
\hline \multirow{2}{*}{ Nomor } & \multicolumn{3}{|c|}{ Derajat Keanggotaan } & \multirow{2}{*}{$\begin{array}{c}\text { Jarak } \\
\text { Maksimum }\end{array}$} & \multicolumn{3}{|c|}{ Cluster } \\
\hline & $\mu_{\mathrm{i} 1}$ & $\mu_{\mathrm{i} 2}$ & $\mu_{\mathrm{i3}}$ & & $C_{1}$ & $C_{2}$ & $C_{3}$ \\
\hline 1 & 0.5399 & 0.4065 & 0.0535 & 0.5399 & 1 & 0 & 0 \\
\hline 2 & 0.0332 & 0.0889 & 0.8778 & 0.8778 & 0 & 0 & 1 \\
\hline 3 & 0.0733 & 0.2087 & 0.7181 & 0.7181 & 0 & 0 & 1 \\
\hline 4 & 0.7101 & 0.2328 & 0.0570 & 0.7101 & 1 & 0 & 0 \\
\hline 5 & 0.8674 & 0.1126 & 0.0200 & 0.8674 & 1 & 0 & 0 \\
\hline 6 & 0.0939 & 0.2191 & 0.6870 & 0.6870 & 0 & 0 & 1 \\
\hline 7 & 0.0925 & 0.7435 & 0.1641 & 0.7435 & 0 & 1 & 0 \\
\hline 8 & 0.2005 & 0.6893 & 0.1103 & 0.6893 & 0 & 1 & 0 \\
\hline 9 & 0.0271 & 0.0629 & 0.9100 & 0.9100 & 0 & 0 & 1 \\
\hline 10 & 0.1485 & 0.3946 & 0.4569 & 0.4569 & 0 & 0 & 1 \\
\hline 11 & 0.0112 & 0.0287 & 0.9601 & 0.9601 & 0 & 0 & 1 \\
\hline 12 & 0.8658 & 0.1086 & 0.0256 & 0.8658 & 1 & 0 & 0 \\
\hline 13 & 0.6449 & 0.3071 & 0.0480 & 0.6449 & 1 & 0 & 0 \\
\hline 14 & 0.0844 & 0.2423 & 0.6734 & 0.6734 & 0 & 0 & 1 \\
\hline 15 & 0.1076 & 0.6780 & 0.2144 & 0.6780 & 0 & 1 & 0 \\
\hline 16 & 0.1230 & 0.6904 & 0.1866 & 0.6904 & 0 & 1 & 0 \\
\hline 17 & 0.0933 & 0.8633 & 0.0434 & 0.8633 & 0 & 1 & 0 \\
\hline 18 & 0.1446 & 0.3856 & 0.4697 & 0.4697 & 0 & 0 & 1 \\
\hline 19 & 0.1600 & 0.6612 & 0.1788 & 0.6612 & 0 & 1 & 0 \\
\hline 20 & 0.0797 & 0.2364 & 0.6839 & 0.6839 & 0 & 0 & 1 \\
\hline$\ldots . .$. & $\ldots . .$. & $\ldots . .$. & $\ldots . .$. & $\ldots . .$. & ...... & ...... & ...... \\
\hline$\ldots .$. & $\ldots . .$. & $\ldots . .$. & $\ldots .$. & $\ldots .$. & ...... & ...... & $\ldots . .$. \\
\hline 149 & 0.0833 & 0.8324 & 0.0843 & 0.8324 & 0 & 1 & 0 \\
\hline 150 & 0.0550 & 0.9257 & 0.0193 & 0.9257 & 0 & 1 & 0 \\
\hline
\end{tabular}

\section{Hasil dan Pembahasan}

Berdasarkan perhitungan yang dilakukan dengan menggunakan prototype aplikasi clustering menggunakan algoritma $K$-Meanscluster data siswa yang terbentuk sebanyak 3 cluster dengan anggotanya terdiri dari :

a) Cluster pertama $\left(\mathrm{C}_{1}\right)$ dengan anggota terdiri dari 1,4,5,12,13,21,22,30,31,36, $37,38,43,44,48,54,55,56,61,62,63,64,65$ ,71,72,78,80,81,85,86,87,88,90,97,102, $108,109,116,121,122,123,126,130,131$, 135,136,137,142,143,147.

b) Cluster kedua $\left(\mathrm{C}_{2}\right)$ dengan anggota terdiri dari $7,8,10,15,16,17,19,25,29$, $32,33,34,41,45,46,47,52,53,57,58,66,70$ ,74,75,76,79,89,93,94,95,96,100,101,10 $3,105,106,107,113,114,115,117,120,12$ $5,129,132,133,134,140,141,144,146,14$ 9,150 .

c) Cluster ketiga $\left(\mathrm{C}_{3}\right)$ dengan anggota terdiri dari 2,3,6,9,11,14,18,20,23,24, $26,27,28,35,39,40,42,49,50,51,59,60,67$ ,68,69,73,77,82,83,84,91,92,98,99,104, $110,111,112,118,119,124,127,128,138$, $139,145,148$.

Berdasarkan perhitungan dengan menggunakan teknik Fuzzy C-Means maka data siswa dikelompokkan kedalam 3 cluster dengan anggotanya terdiri dari :

a) Cluster pertama $\left(\mathrm{C}_{1}\right)$ yang anggotanya terdiri dari $1,4,5,12,13,21,22,30,31,36$ ,37,38,43,44,48,55,56,61,63,64,65,71,7 $2,78,81,85,86,87,88,90,97,102,108,109$, $116,122,126,130,131,135,136,142,143$, 147.

b) Cluster kedua $\left(\mathrm{C}_{2}\right)$ dengan anggotanya terdiri dari 7,8,15,16,17,19,25,29,32, ,41,45,46,47,52,53,54,57,58,62,66,70,7 $4,76,79,80,93,94,95,96,100,101,103,10$ $5,106,107,113,114,115,117,120,121,12$ $3,125,129,132,133,134,137,140,141,14$ $6,149,150$.

c) Cluster ketiga $\left(\mathrm{C}_{3}\right)$ dengan anggotanya terdiri dari 2,3,6,9,10,11,14,18,20,23, $24,26,27,28,33,35,39,40,42,49,50,51,59$ $, 60,67,68,69,73,75,77,82,83,84,89,91,9$ $2,98,99,104,110,111,112,118,119,124,1$ $27,128,138,139,144,145,148$. 


\section{Analisis Komparasi Kinerja Algoritma Fuzzy C-Means dan K-Means}

Untuk menganalisis komparasi kinerja kedua algoritma tersebut dalam melakukan pengelompokan data siswa berdasarkan prestasi akademik, data nilai siswa akan dikelompokkan kedalam 3 cluster dengan ketentuan cluster pertama $(\mathrm{C} 1)$ rata-rata nilai siswa adalahlebih besar atau sama dengan 7.24, dan cluster kedua dengan rata-rata nilai siswa lebih besar atau sama dengan 6 dan lebih kecil dari 7.24, sedangkan untuk cluster ketiga rata-rata nilai siswalebih kecil dari 6. Dari hasil interasi kedua algoritma tersebut dapat kita lihat bahwa hasil interasi algoritma $K$ Means lebih akurat dalam melakukan pengelompokan data siswa, seperti terlihat pada data nomor 10 dan nomor 33 dimana nilai rata-rata siswa adalah 6 dan 6.14 pada algoritma K-Means data siswa dikelompokkan pada cluster kedua sesuai dengan ketentuan yang diinginkan sedangkan hasil cluster algoritma Fuzzy $C$ Means data siswa dikelompokkan pada cluster ketiga yang tentunya tidak sesuai dengan syarat yang diinginkan sebelumnya. Jadi dapat disimpulkan bahwa algoritma $K$ Means lebih tepat digunakan untuk mengelompokkan data siswa. Perbedaan hasil clustering algoritma $K$-Means dan Fuzzy C-Means dapat kita lihat pada tabel 6 berikut :
Tabel 6. Hasil clustering kedua algoritma

\begin{tabular}{|c|c|c|c|c|}
\hline lanon" & lama & 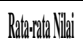 & 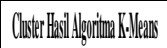 & 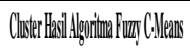 \\
\hline 1 & Dedef Siatranan & $7 x$ & a & a \\
\hline$!$ & Ininilnavea & is & $B$ & $B$ \\
\hline "'! & 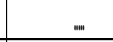 & $m$ & 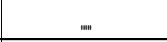 & $\ldots$ \\
\hline "'! & 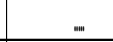 & m" & 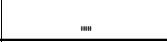 & $\ldots$ \\
\hline l & 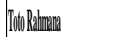 & 48 & $B$ & $B$ \\
\hline $\mathbb{1 1}$ & 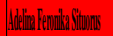 & 6 & 0 & B \\
\hline ..' & 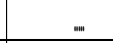 & 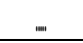 & 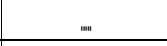 & 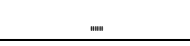 \\
\hline "'.' & ."' & 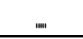 & 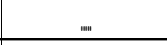 & 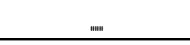 \\
\hline$\eta$ & lyensadith & 6.t & 0 & 0 \\
\hline 3 & |Wmphathen & bit & 0 & B \\
\hline H & 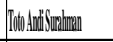 & 6.8 & 0 & 0 \\
\hline ."' & 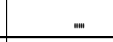 & "m! & m!' & "ant \\
\hline ."' & 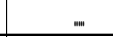 & 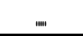 & 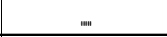 & 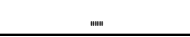 \\
\hline 3 & Danssing & 612 & 0 & 0 \\
\hline 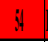 & 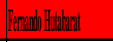 & 13.5 & Q & 0 \\
\hline$i$ & Regalditim & 7.6 & Q & a \\
\hline ."' & 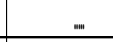 & "m! & "m! & "an' \\
\hline "'m' & 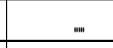 & 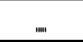 & 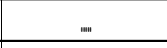 & 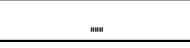 \\
\hline at & 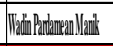 & 726 & a & a \\
\hline a. & Betaligin & 1.4. & a & 0 \\
\hline B & Pidinlyigin & 8.2 & a & a \\
\hline "'m' & 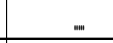 & m"' & m"' & ."un \\
\hline "'m & ."' & 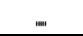 & ."' & ."u \\
\hline it & Horivaliati & 11.4 & 0 & $Q$ \\
\hline$\pi$ & 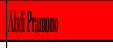 & 6.1 & 0 & $B$ \\
\hline 76 & Praxplathrin & 7.16 & 0 & 0 \\
\hline $\mathrm{m}$ & 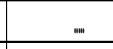 & 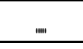 & "'m & 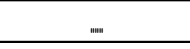 \\
\hline "'m' & 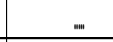 & "'m & 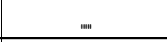 & .m. \\
\hline 7$)$ & Thos Sildatarer & 7,118 & 0 & 0 \\
\hline $\mathbb{1}$ & Tongrimg & 12.8 & a & 0 \\
\hline 81 & Baty lahin & 83 & a & a \\
\hline "'m' & "'m & 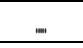 & 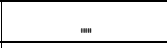 & 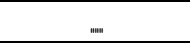 \\
\hline "'!' & ."' & "m! & "m! & 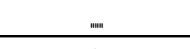 \\
\hline 8 & 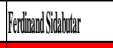 & 81 & a & a \\
\hline$\theta$ & 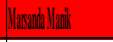 & 616 & 0 & $B$ \\
\hline y & 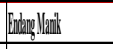 & it. & a & a \\
\hline "m.' & ."' & 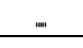 & 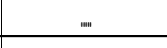 & $\ldots$ \\
\hline "m.' & ."' & "'! & 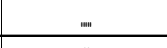 & 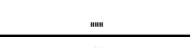 \\
\hline 1.1 & Dilib bin & 6.66 & 0 & 0 \\
\hline 111 & Whathather & 7.6 & a & 0 \\
\hline 12 & 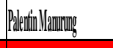 & 8NA & a & a \\
\hline 103 & Pland Singy & 0.1 & a & 0 \\
\hline -"'! & ."' & 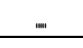 & 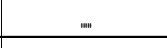 & $\ldots$ \\
\hline ."' & 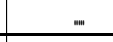 & 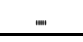 & 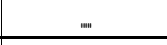 & 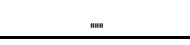 \\
\hline 116 & ThinBbidudtar & 1,66 & a & a \\
\hline 137 & Natithragh & 7.8 & a & 0 \\
\hline 18 & Bandilinges & if & $B$ & $B$ \\
\hline "'m' & 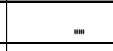 & 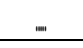 & 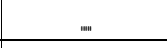 & 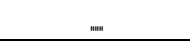 \\
\hline $1 / 3$ & Cadraxdibilis & 854 & a & a \\
\hline $1 H$ & Brishititi & (ill) & 0 & $B$ \\
\hline 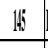 & Rasalati & ill & $B$ & $B$ \\
\hline "'m' & 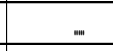 & 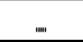 & "'m & 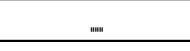 \\
\hline 1.4) & Haifingy & 6.6 & 0 & 0 \\
\hline 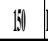 & Pramaxiliat & 691 & 0 & 0 \\
\hline
\end{tabular}




\section{Kesimpulan}

Teknik clustering dapat digunakan untuk meningkatkan prestasi akademik siswa dengan cara melakukan clustering data siswa berdasarkan kemampuannya melalui prestasi nilai akademik, sehingga pihak akademik dapat memantau perkembangan prestasi siswa dan dapat menentukan kebijakan yang tepat dalam menentukan metode pengajaran yang tepat sesuai dengan kemampuan siswa. Berdasarkan hasil penelitian yang dilakukan teknik clustering yang paling tepat digunakan adalah metode $K$-Means.

\section{Daftar Pustaka}

Maria E. S., et al, 2015, Sistem Penentuan Jurusan Sekolah Menengah Atas Negeri 1 Karangmojo, Seminar Nasional Teknologi Informasi dan Multimedia 2015, STMIK AMIKOM Yogyakarta, ISSN : 2302 -3805 .

Aniq Noviciatie Ulfah dan Shofwatul Uyun, 2015, Analisis Kinerja Algoritma Fuzzy C-Means dan $K$ Means pada Data Kemiskinan, Jatisi Vol. 1 No. 2, ISSN : 2407 - 4322

Suprihatin, 2011, Clustering K-Means Untuk Penentuan Nilai Ujian, JUSI Vol. I No. 1, ISSN : 2087 8737.

Mardiani, 2014, Perbandingan Algoritma K-Means dan EM Untuk Clusterisasi Nilai Mahasiswa Berdasarkan Asal Sekolah, Citec Journal Vol. I No. 4, ISSN : 2354 5771

Erfan Agil Putranto, et al, 2012, Sistem Pendukung Keputusan Penjurusan Siswa Kelas X SMA Negeri 2 dengan Metode Fuzzy C-Means dengan Penggunaan Daya Dukung Minat, JURNAL ITSMART Vol. 1 No. 2, ISSN : $2301-7201$
Cakra Ramadhana, et al, 2013, Data Mining dengan Algoritma Fuzzy C-Means Clustering dalam Kasus Penjualan di PT. Sepatu Bata, Seminar Nasional Teknologi Informasi dan Komunikasi Terapan, ISBN : 97926-0266-6.

Tb. Ai Munandar, et al, 2013, Clustering Data Nilai Mahasiswa Untuk Pengelompokan Konsentrasi Jurusan Menggunakan Fuzzy Cluster Means, Seminar Nasional Aplikasi Teknologi Informasi (SNATI) Yogyakarta, ISSN : 1907 5022.

Idni Irsalina, et al, 2014, Clustering Gender Berdasarkan Nilai Maksimum Minimum Amplitudo Suara Berbasis Fuzzy C-Means (FCM), Prosiding SNATIF Ke-1, ISBN : 978-6021180-04-4.

Idni Irsalina, et al, 2014, Clustering Gender Berdasarkan Nilai Maksimum Minimum Amplitudo Suara Berbasis Fuzzy C-Means (FCM), Prosiding SNATIF Ke-1, ISBN : 978-6021180-04-4

Anita Budi Hastuti, et al, 2013, Implementasi Metode Fuzzy CMeans dan TOPSIS Dalam Membangun Sistem Pendukung Keputusan Penentuan Jurusan SMA (Studi Kasus : Penentuan Jurusan di SMA Negeri 1 Wonosari), JURNAL DASI, Vol. 14 No. 2, ISSN : 1411 3201.

Miftahus Sholihin dan Aizatus Sholikhiyah, 2012, Prediksi Tingkat Kelulusan Siswa Dalam UAN di SMP Negeri 2 Deket Dengan Menggunakan Metode Teorema Bayes, Jurnal Teknika, Vol. 4 No. 2, ISSN : 2085 -0859 . 